\title{
Ocean Eddies in the 1539 Carta Marina by Olaus Magnus
}

\author{
H. Thomas Rossby \\ University of Rhode Island - Narragansett, Rhode Island USA
}

\author{
Peter Miller \\ Plymouth Marine Laboratory • Plymouth UK
}

In 1539 Olaus Magnus, an exiled Swedish priest living in Italy, published a remarkably detailed map of the Nordic countries, from Iceland in the west to Finland in the east. The map, called 'Carta Marina', introduced a scope of information about these countries that broke completely new ground in terms of comprehensiveness and general accuracy. The geographical outline of the Nordic countries is quite accurate and the map includes all the major island groups such as the Faroes, Orkneys and Shetland Islands. In addition to the geography and numerous ethnographic sketches, the map also provides, as it name indicates, an extraordinary wealth of information about the waters surrounding the Nordic countries.

Olaus Magnus gives the ocean striking presence by drawing in sea monsters, some more strange than others, sailing vessels, fishing boats and kayaks. He also gives the ocean itself unusual presence or 'texture' in the form of thin dotted lines drawn horizontally everywhere there is water. But he departs from this lineal pattern in one particular area: Extending east from Iceland and passing north of the Faroes but not all the way to Norway, he draws in a band of whorls of remarkable definition. The location of these corresponds almost perfectly with the Iceland-Faroes Front, a major surface front. Nowhere else in the chart do whorls appear in such a systematic fashion. This note suggests that they were drawn deliberately to indicate the special nature of the waters east of Iceland, and as such would appear to be the earliest known description of mesoscale eddies in the ocean. This is a region of high thermal contrast where warm North Atlantic waters from the south and very cold waters from north of Iceland come together and mix. It seems likely that Olaus Magnus got the information from mariners of the Hanseatic League operating out of northern Germany cities, many of which he is known to have visited and lived in both before and after he was exiled from Sweden.

\section{Introduction}

Starting in the 1400s with the rapidly expanding exploration by the Mediterranean countries, production of maps to aid navigators grew enormously. From the Atlantic in the west to the Black and Red Seas in the east, these maps of the Mediterranean depict the shape and proportions of the Mediterranean Sea quite well. Any one familiar with reading maps will recognize Gibraltar, Italy, the Balkans, Egypt and Palestine. Many include the British Isles and Germany, but not Scandinavia. In the early editions of the Ptolemy atlas Scandinavia does not appear. But in 1482 Nicolaus Germanus (the Ulm atlas) drew a map in which Denmark, southern Sweden and Norway clearly appear with names of numerous regions and towns. An updated version of this map was compiled by Martin Waldseemüller in 1513. A significant step forward occurred in 1532 with the Jacob Ziegler map (Nordenskiöld, 1889) which for the first time shows the full length of the Scandinavian peninsula (albeit connected with Greenland in the north). Finland also appears for the first time as distinct from the rest of Scandinavia.

Against this backdrop of an as yet poorly developed cartography of the Nordic countries, Olaus Magnus in 1539 published his Carta Marina, a stunningly detailed map spanning a region from northern Germany in the south to the Barents Sea in the north, Greenland in the west to Russia in the east (Figure 1). The result of many years of travels and note keeping, the map provided a wealth of information about the Nordic countries. The major island groups in the North Atlantic are all represented. The very long coastline of Norway stands out clearly, and the coastal regions around the Baltic Sea emerge in considerable detail. The map also includes an explanatory key, region by region. Physically, the map broke new grounds in terms of size: it consists of nine wood lithographs, which fit together into a nearly seamless whole, $1.7 \mathrm{~m}$ wide and $1.25 \mathrm{~m}$ high. Two copies exist today, one in Munich, Germany and the other in Uppsala, Sweden. While interest in the map quite obviously focuses on the geography and peoples of the Nordic countries, one can also appreciate why Olaus gave the map the name Carta Marina, for unlike almost all other maps that had been published by that time (or to come later) he gave extraordinary attention to the ocean itself, particularly the waters west of Scandinavia. 


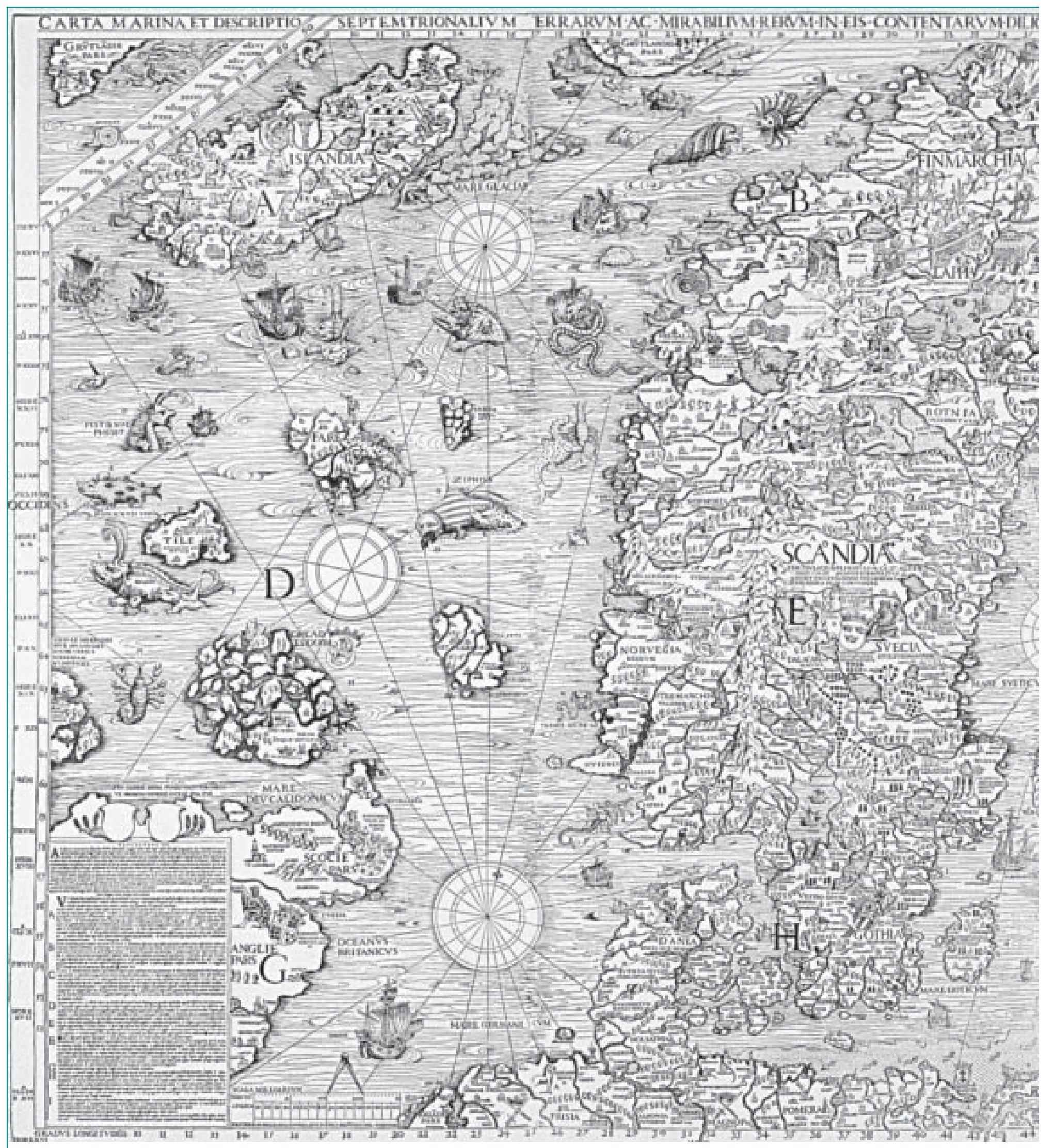

Figure 1. The 1539 Carta Marina by Olaus Magnus (original size $1.7 \times 1.25$ m). It is on display at Carolina Rediviva, the library of the University of Uppsala, Uppsala, Sweden. (Reproduced with permission from Uppsala University Library.) 


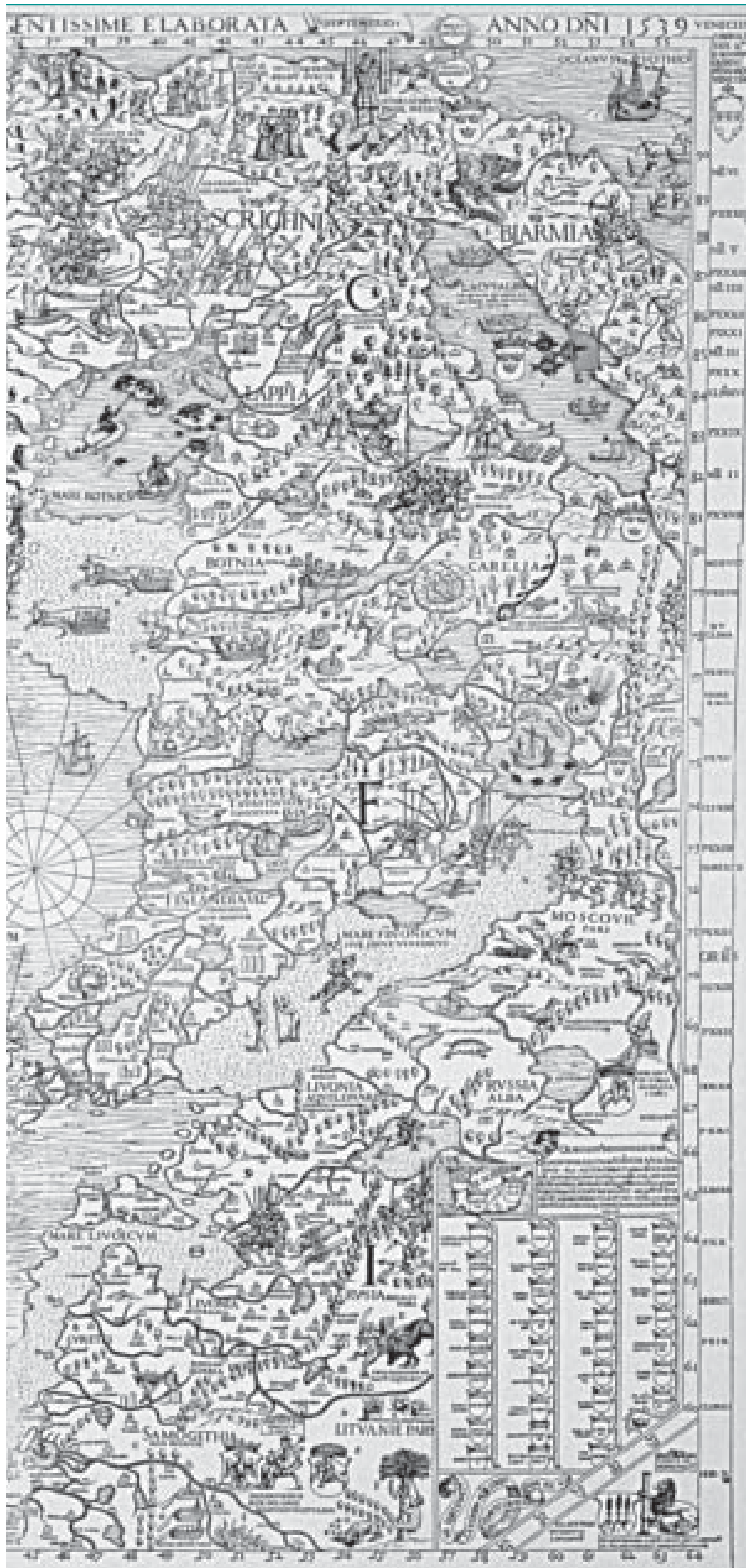

The ocean teems with activity, and significantly, he gives the ocean itself a physical presence. He does this by drawing everywhere thin dotted lines. While 'stippling' of the ocean had been done before, for example thin dashed lines indicate water in the 1490 Ptolemy World Atlas, in Carta Marina the lines are drawn with far greater care, including an occasional wiggle or swirl to break the monotony. But Olaus departs from this approach quite conspicuously in one area: extending east from Iceland and passing north of the Faroes the lines are replaced by a band of whorls (circular patterns). Nowhere else in the map does one find anything like these, it seems clear they are intended to be there. The question we consider in this note is why did he draw in these whorls and what do they represent, for he provides no explanation in his description of the map.

Later, in 1555, Olaus also published a major treatise called 'HISTORIA DE GENTIBUS SEPTENTRIONALIBUS' (History of the Nordic Peoples) which in 22 chapters expands upon his Carta and describes all aspects of life and living conditions in the Nordic countries in the early 1500s. It was a truly major piece of work, and soon after the book's publication in Latin, translations appeared in many European languages including German in 1567 and English in 1638, but not until the early 1900s in a Scandinavian language, Swedish. But the book too is silent about the meaning of the whorls in Carta Marina. In this note we attempt an oceanographic explanation for these, but before we go into this in detail, we first give some background on Olaus and the sources of information he drew upon in preparing his map.

\section{Olaus Magnus}

Olaus was born in 1490 in Linköping in Sweden and died in Rome in 1557. He became vicar in Stockholm and (cathedral-) dean in Strängnäs. During the 1520s he undertook various diplomatic missions on behalf of King Gustav Vasa, but his relationship with the king became increasingly strained after the king forced Sweden to convert to Lutheranism. Olaus remained a Catholic and after many years of travel around the continent settled down in Italy where he completed his work on Carta Marina and his future 'HISTORIA...'. The Pope appointed him to Archbishop of Sweden in 1544 (after the death of his brother who also was Archbishop in exile), but of course as a Catholic in exile he couldn't assume his post in Uppsala.

Olaus was an itinerant traveler and visited many of the areas he was later to depict in his map. Already as a 15 year old he passed through Oslo during a trip around southern Norway. Much of his education he obtained at German universities during the years 1510-1517. At the behest of the Catholic Church he spent a year (15181519) in northern Sweden and Norway fighting the Lutheran heresy and selling indulgences. From his later work it is clear he was deeply impressed by the people he met and landscapes he visited. Upon his return to 


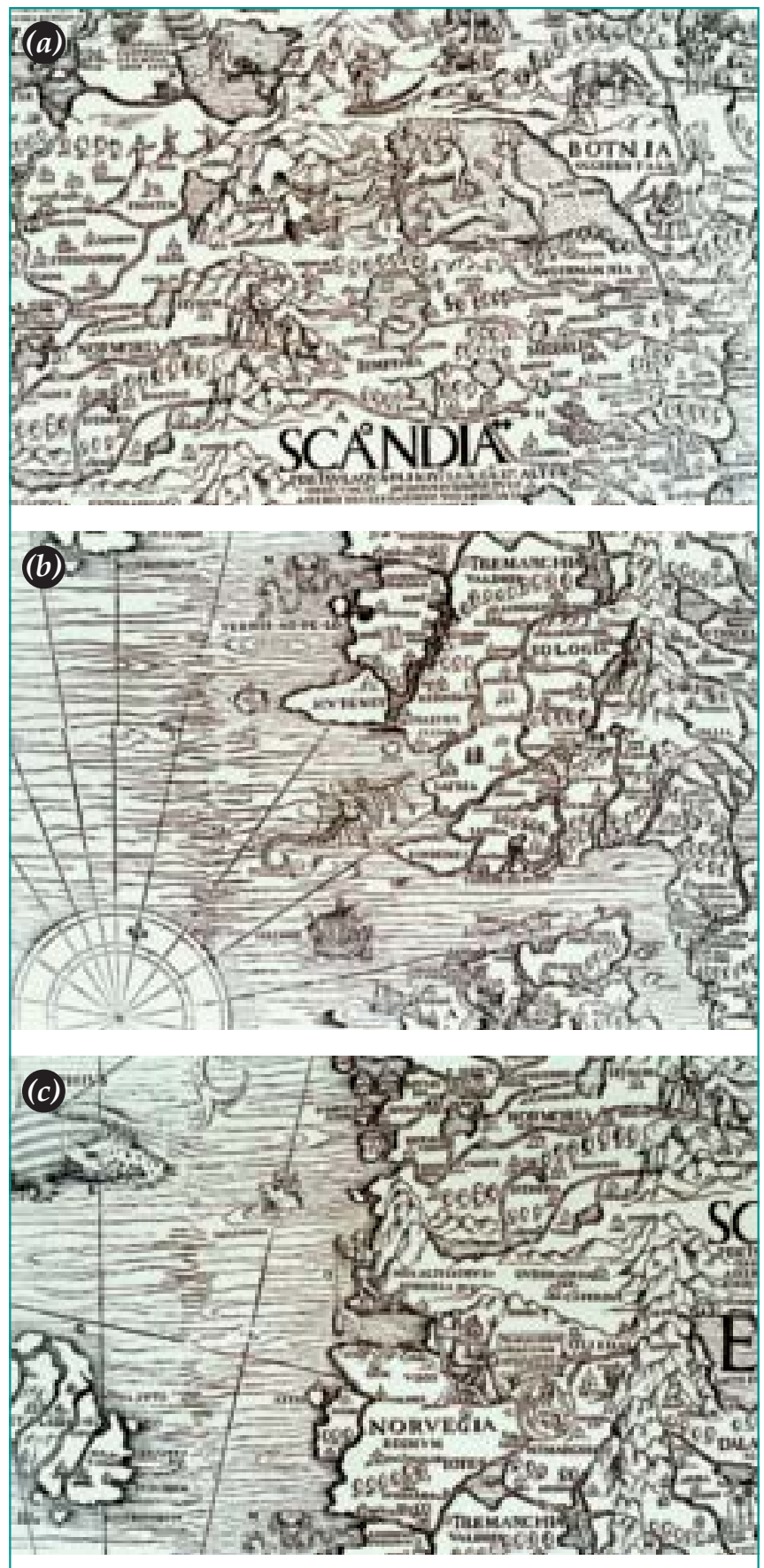

Figure 2. A few close-ups from Carta Marina illustrating life in Scandinavia. These skillfully executed woodcuts from Olaus's original show (a) a winter scene from the mountains including a possible 'self-portrait' of Olaus Magnus on his trek from Sweden to Norway winter 1517-1518, (b) a swimmer being defended by a ray from a school of attacking fish, and (c) a man measuring water depth.

Stockholm, he became vicar and was in the city at the time of the Stockholm bloodbath (November 1520) when King Christian II of Denmark took revenge on an earlier revolt against him and beheaded close to 90 people from the Swedish clergy (including a close call for Olaus himself) and nobility. In 1523 Olaus' two-year older brother Johannes was elected to Archbishop of Sweden, and the following year King Gustaf Vasa sent Olaus to Rome to obtain the Pope's blessing of the election. He was never to see Sweden again. During the 1520s Olaus was occupied with a number of diplomatic assignments in Italy, Germany, the Netherlands and Poland seeking to renegotiate heavy debt burdens Sweden owed the Hansa (Richter, 1967). Thus, during these diplomatic journeys he visited many Hanseatic ports, from the Baltic in the east to the North Sea in the west including a trip by sea from Hamburg to the Netherlands. He also resided in Danzig (Gdansk) for several years in the late 1520s. Given his evident curiosity about nature and society, he no doubt acquired much information about life at sea and sailing conditions. After Gustaf Vasa officially converted Sweden to Lutheranism in 1527 relations with the firmly Catholic brothers grew increasingly strained, and eventually the king stripped Olaus of his official positions and confiscated his remaining belongings in Sweden.

While Olaus remained a firm Catholic his entire life, he clearly maintained a deep love for his home country. How else explain the love and care with which Carta Marina was put together, including the incredible richness of information about life and living conditions throughout the far north. Similarly, his 1555 'HISTORIA...' discusses in extensive detail all aspects of life and living, be it farming, fishing, snow ball fights, protecting homes against enemies, bird, animal and marine life, etc in the countries of his early years. Although he gradually established a rather secure life in Rome, one can imagine that at heart he must been very homesick. He died in 1557. Grape (1970) provides extensive biographical information on the life and work of Olaus Magnus.

\section{Carta Marina}

Olaus worked on his Carta Marina over a 12-year period, beginning in 1527, just at the time Sweden officially converted to the Lutheran faith, and completing it while a guest of Prelate Hieronymous Quirinus in Venice in 1539 where the map was published. Later that same year he also published a more complete commentary to the map 'Opera breve'. It is far beyond the scope of this note to discuss Carta Marina either as a whole or in detail, but the interested reader will find considerable biographical information about Olaus as well as a comprehensive analysis of the map in the book by Richter (1967). See also the article by Granlund (1951), which is written in English. Carta Marina is packed with an extraordinary amount of information. It is not the first map to show Scandinavia as a peninsula, but it is one of the first to give it, Finland and parts of Russia, roughly correct proportions. It is the first map to fully portray the Baltic, the Finnish Gulf and Gulf of Bothnia in the north. The map also covers northern Scotland, the Hebrides, Orkneys, Shetlands, Faroes, Iceland and Greenland in the west. He also includes a non-existent 


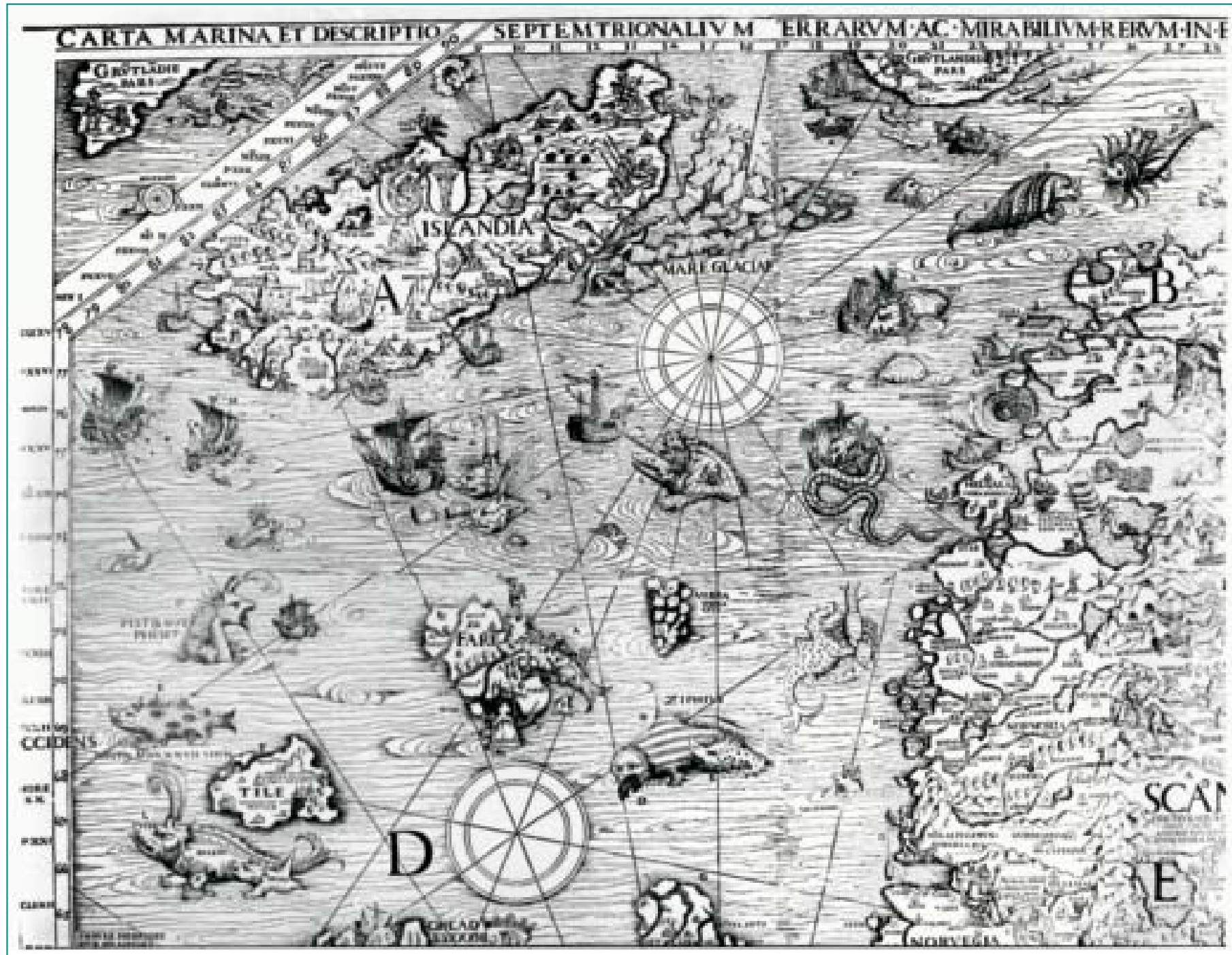

Figure 3. Detail of Carta Marina between Iceland, the Faroes and Norway. Note the sea ice spreading east along the north coast of Iceland and the many whorls in the ocean. The famous tidal whirlpool in the Lofoten Islands is clearly indicated.

island, Tile, which some have speculated may be related to the mythical far northern community Thule. (Curiously, its location on the map puts it near St. Kilda, a small, at times inhabited island group west of the Hebrides.) The list of towns, lakes, and regions is far more comprehensive than any map either preceding it or to follow. In addition to the map information it includes numerous small pictorials depicting farming, fishing, hunting, milking, and wolves unable to attack moose on slippery ice (Figure 2). Little sketches illustrate other maps of the period, such as the world maps by Waldseemüller (1516) and Ribero (1529), but in Carta Marina they clearly serve to convey information about life and living conditions. Thus it is far more than a map or chart in the usual sense.

The oceans include a similar richness of information, indeed the presence and vitality of life at and in the seas fully justify the map's name. A close-up of Carta Marina between Iceland and Norway (Figure 3) reveals enormous detail about shipping, life in the sea, drift ice north of Iceland, including a stranded polar bear on a floe. Some creatures are recognizable including whales, sea lions, walrus, crab and lobster, but others, both to shape and size, more likely reflect a lively reinterpretation of hearsay from fishermen and sailors. His giant sea snakes and other monsters clearly impressed the imagination of other mapmakers, as can be seen for example in the Galleria delle Carte Geografiche at the Vatican (Knauer, 1981). Knauer even suggests that some of these monsters, particularly those attacking vessels from protestant countries (such as Gothi and Dani), are not a coincidence. The sea battle between Hamburgen and Scott may reflect the commercial tensions between the Hansa and England. On the surface of the ocean Olaus draws ambergris, driftwood along the coast of Greenland and Eskimos kayaking in the far north. The compass rose and lines indicate sailing directions. Recalling that 500 years ago mariners could determine latitude and magnetic direction, but not longitude, it was very common to sail along either 

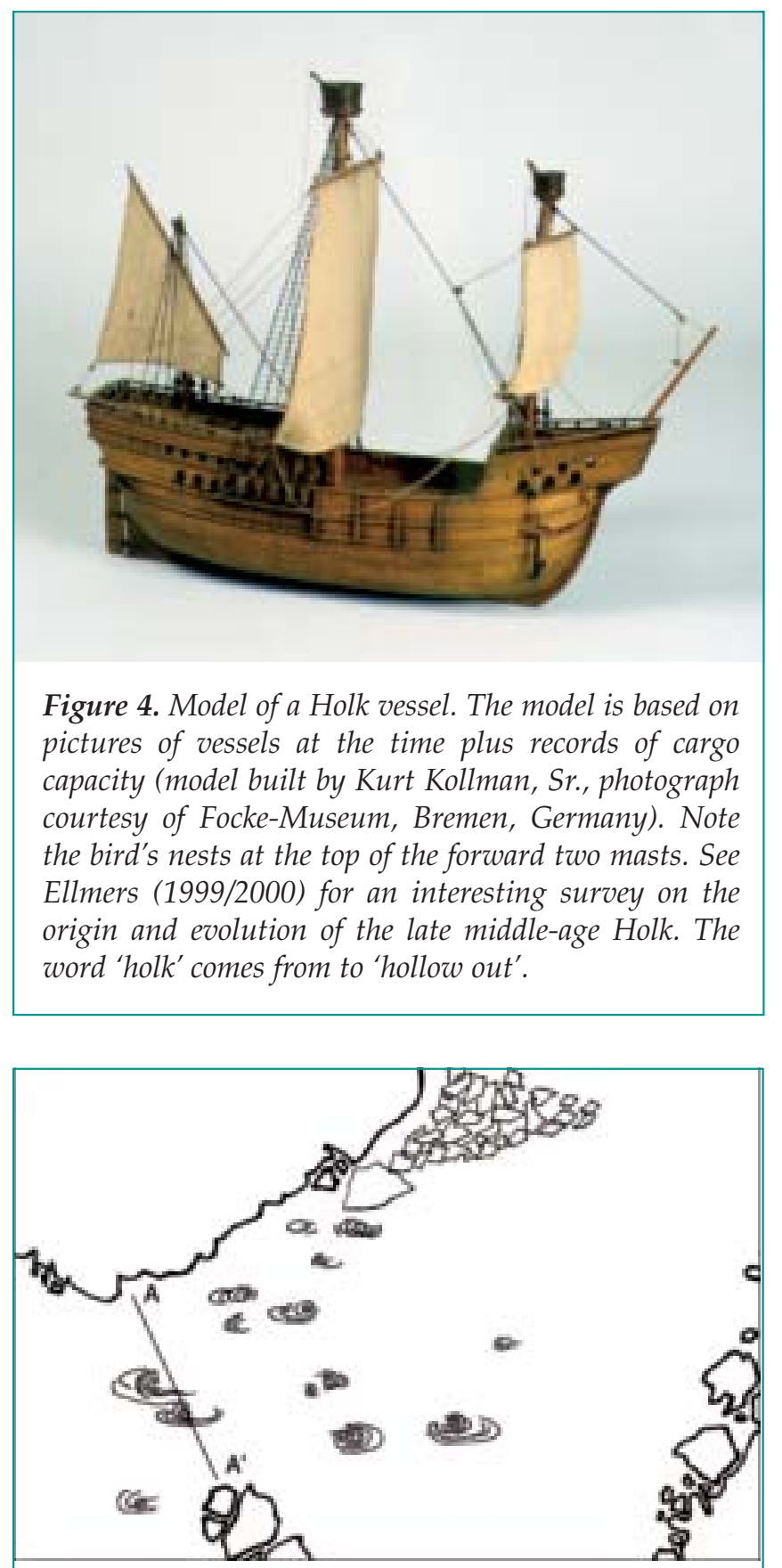

Figure 5. Simplified drawing of Figure 3 showing only the drift ice and whorls. The line $A-A^{\prime}$ depicting the shortest distance between Iceland and the Faroes is just over $400 \mathrm{~km}$.

lines of constant latitude or constant direction.

The scale of the chart as a whole is roughly 1:5 700 000 , or about one half this if we limit ourselves to the Iceland, Faroes, Norway region in Figure 3. As indicated by the number of ships, these waters were heavily trafficked by merchant marine vessels from Scandinavia, Germany and England. During the cold centuries of the little Ice Age (roughly 1300 to 1800s) Iceland often experienced extensive sea ice formation along its northern and eastern coasts during the winter months (Lamb, 1977). Assuming an east- and southward flow along the northern coast of Iceland then as now, cold melt water would meet warm waters from the Atlantic on the SE coast of Iceland, today near the town of Eystrahorn (Stefánsson, 1972). In spring the contrast in temperature where these waters meet east of Iceland would have been enormous, presumably as large as it is today, $\sim 5^{\circ} \mathrm{C}$. Nowhere else in the Northeast Atlantic can one find waters of such large thermal contrast so closely juxtaposed. Unquestionably shippers (and very likely the Norse Vikings some 500 years earlier) sailing to Iceland each spring to conduct trade were well aware of these contrasting bodies of warm and cold water.

\section{The Hansa}

We mentioned earlier that Olaus traveled extensively in northern Germany visiting the major Hansa towns. This is relevant because the Hansa was responsible for much of the trade between Iceland and the continent. Until the middle 1400s trade with Iceland was handled by Norway, but increasingly, the Hansa bypassed its Kontor (office or hub) in Bergen and operated directly between Germany and Iceland. In earlier times the primary vessel used was the one-masted Kogge. This was gradually replaced by the larger Holk with its rounded hull. Towards the late 1400s a major change in construction took place when carvel building replaced the earlier klinker design, i.e. hull planks were set up flush or next to each other instead of partially overlapping. This led to a smoother (less friction) and sturdier structure allowing the vessels to operate with greater confidence on the high seas than in the past. The holks, typically $30 \mathrm{~m}$ in length, had a cargo capacity of about 150 tons (Figure 4). The ships transported grain, beer, wood, and textile products to Iceland. The most important return cargo, by far, was fish, mostly dried cod but also salted. Other products included sheepskins, butter and other fish such as salmon from the many freshwater rivers. Later in the 16th century sulfur became an increasingly important export item.

In a typical year, up to perhaps 25 ships would leave Hamburg and Bremen in late March-early April for Iceland (Baasch, 1889). Assuming a one-month journey they would arrive in Iceland early in May when the length of day and twilight was approaching 24 hours. Sailing over the North Sea, between the Orkneys and Shetland and across the warm Shetland Current, the vessels might encounter the very cold waters on their approach to Iceland. In spring the winds drop in intensity. Nonetheless, to avoid the strong westerlies south of Iceland and increase the chances of a tailwind, they would benefit from passing north rather than south of the Faroes (the vessels often put into the Faroes along the way). But by assuming a more northerly route they increase the likelihood of encountering cold water. Even today, to avoid strong headwinds, ships en route to western Greenland from the North Sea steer a great 


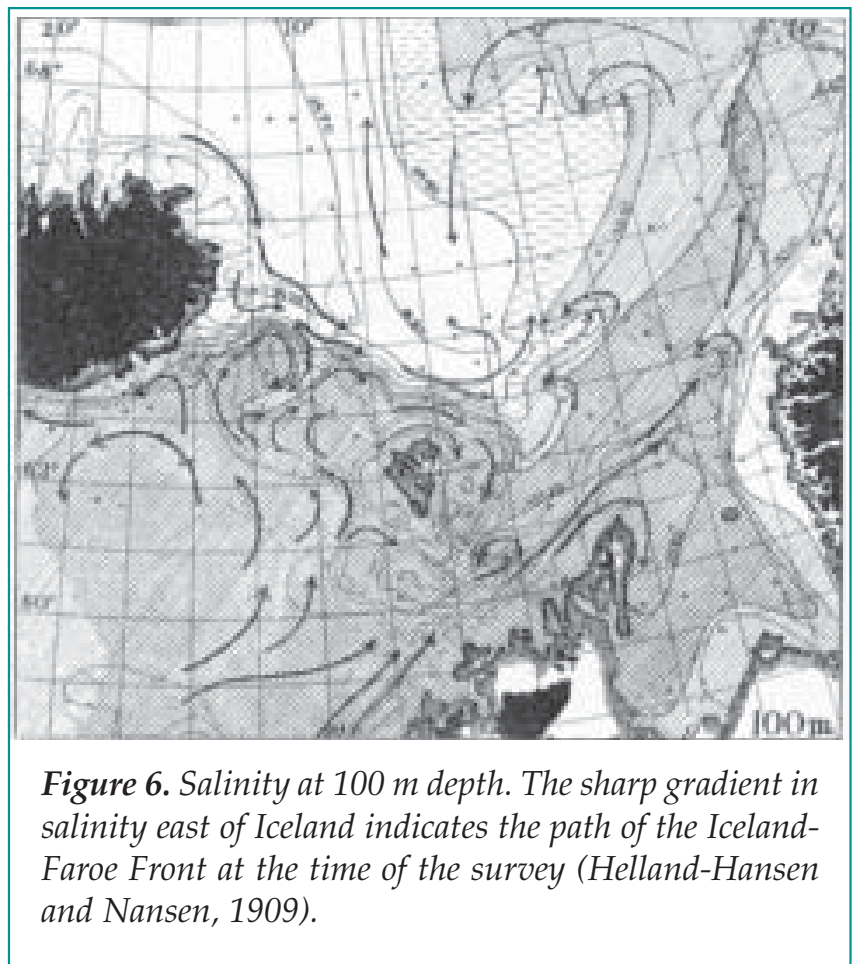

circle route passing close to Iceland westbound and straight east from Cape Farewell when eastbound.

The primary navigational tools in the late 1400s to early 1500s consisted of the compass for direction and the cross-staff to determine solar elevation. Thus vessels preferred to sail at constant heading or along a constant latitude. They used the sounding line to measure water depth, but the log line used to estimate speed through the water (and hence distance) had not yet come into widespread use (Ellmers, 1999/2000). So far as is known, charts like the portolan charts of the Mediterranean did not yet exist for these Nordic waters, but the 'shippers' (from shep-her, i.e. ship's master) had detailed notes about coastlines in their 'rutter' as these books were called in England (Waters, 1958) or 'Seebuch' in German (Ellmers, 2002). On deck much of the time the mariners must have been very keen observers. They would notice changes in water temperature, currents, wind direction, waves and swell. They would notice differences in the color of water and marine life between warm waters from the North Atlantic Current and cold waters from north of Iceland. These observations of sea conditions became part of the knowledge base to help ensure that they would reach their destinations safely.

It seems plausible that Olaus learned about the remarkable waters east of Iceland while visiting Hanseatic ports, and perhaps especially on his Hamburg-Netherlands trip (Richter, 1967). The mariners may have told him about ice conditions, pools of cold water, winds and sea conditions, and about the marine life; and given his evident curiosity he would be one to ask. Perhaps what struck mariners and him the most was the remaining ice along the north coast in Spring and the patches of cold waters, which, we conjecture, he sought to portray as whorls in his Carta Marina.

\section{The Whorls}

To simplify our study we redraw Carta Marina retaining only the eddy and ice field in relation to Iceland, the Faroes and Norway (Figure 5). The whorls seem to be an extension of the sea ice north of Iceland suggesting that they represent pools of cold water. Given that the shortest distance (line $\mathrm{A}-\mathrm{A}^{\prime}$ ) between Iceland and the Faroes is just over $400 \mathrm{~km}$ and given that some 3 whorls might fit in this distance, we estimate that the largest whorls approach an order of 100 $\mathrm{km}$ in diameter. The whorls vary in size, some appear to swirl cyclonically (anticlockwise) and others in the opposite direction, but whether these variations in size and rotation are intentional we do not know. But the realism of this pattern of whorls readily matches what we might draw of an eddy field today. Significantly, almost all whorls lie to the north of line A- $\mathrm{A}^{\prime}$, the shortest distance between the Faroes and Iceland. Note also that they do not extend all the way over to Norway, a point we return to below.

While we can't rule out that oceanic conditions differed during the Little Ice Age 500 years ago, the fact that cod fishing was the major source of livelihood in Iceland, the Faroes, and all along the Norwegian coast up to Finnmarken in the far north, it seems plausible that the spread of warm waters from the Subpolar Front (the northern branch of the Gulf Stream) had a similar pattern to that of today. This in turn suggests that the Iceland-Faroe Front (IFF) assumed about the same path then as now; the topography of the IcelandFaroe ridge almost certainly plays a major role in determining its mean path. A hint at the long-term stability of the IFF might be found in a survey of salinity at 100 $m$ depth conducted almost 100 years ago (HellandHansen and Nansen, 1909), shown here in Figure 6. This early yet excellent example of the systematic hydrographic survey technique developed by the Norwegians puts the IFF exactly where it is today (Hansen and Østerhus, 2000). In this study the path of the front has a (weak) meandering pattern with a halfwavelength of about $70 \mathrm{~km}$, i.e. comparable to the whorls in Carta Marina. Figure 6 shows clearly the striking contrast in salinity between the warm saline waters south and cold fresh waters north of the Iceland-Faroe ridge.

Clouds cover the northeast Atlantic most of the time, but when conditions permit satellites can measure sea surface temperature (SST) with a thermal and spatial resolution of $0.1^{\circ} \mathrm{C}$ and $1.1 \mathrm{~km}$, respectively. Further, with only modest loss of small-scale detail, one can composite a number of images to remove much of the cloud coverage. The left panel in Figure 7 

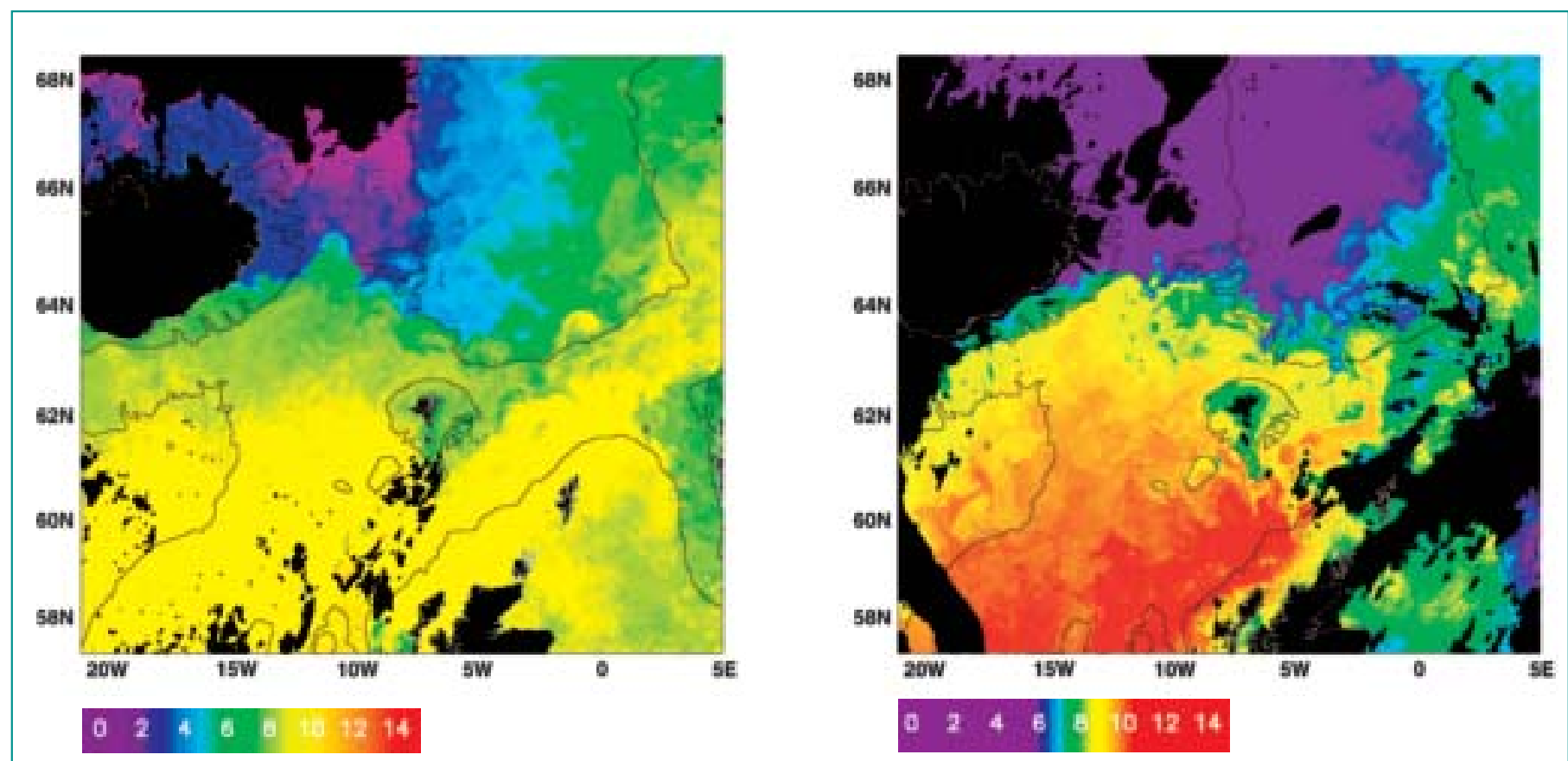

Figure 7. Two satellite images of sea surface temperature. The left panel shows a 7-day composite (May 5-12, 2002) of once/day high resolution AVHRR images with $1.1 \mathrm{~km}$ spatial resolution. Black areas without a white border have no data due to persistent cloud coverage. The right image shows a single snapshot of SST from April 18, 2003. The expanded color range emphasizes the temperature variations in the frontal region.

shows a one-week composite from May 2002, at the time our seafarers would be approaching Iceland. The contrasting waters to either side of the IFF show up clearly at all times, and in spring can exceed $5^{\circ} \mathrm{C}$ in temperature. Sometimes the temperature contrast can appear very sharp, suggesting a narrow front, at other times the front appears to be rather broad. In this image the IFF shows up as a well-defined meandering front, not unlike the salinity front in Figure 6. The right panel shows SST on April 18 2003, in early spring. Only very rarely does one get such a clear view of the NE Atlantic in a single snapshot. The IFF close to Iceland heads almost straight NE, but after turning SE becomes highly convoluted, breaking up into numerous eddies including a very cold but elongated one halfway between the Faroes and Iceland. The SST images indicate that shippers approaching Iceland will experience large variations in temperature, on scales of several tens to a hundred kilometers. After crossing the warm Shetland Current in the lower right of Figure 7, contact with the cold waters would seem quite bracing to seafarers from the continent!

A detailed analysis of the front and its meandering statistics lies beyond the scope of this study, and we should be careful not to inter-compare observations with the whorls in Carta Marina too closely. But the SST images give us an insight to what sailors 500 years ago might have experienced. They reveal striking contrasts in temperature across the IFF and warm and cold eddies north and south of the front. At times the region seems fairly simple as in the left panel of Figure 7, at other times rather messy as in the right panel. Further, as Figure 6 indicates, the IFF extends below the surface, and in fact it extends to the bottom all along the northern slope of the Iceland-Faroe ridge. We might add here that the difference in water properties across the front (dense, cold water north, light, warm water south) leads to a substantial pressure difference across the front that maintains a large transport of warm water, $\sim 3$ to $4 \times 10^{6} \mathrm{~m}^{3} \mathrm{~s}^{-1}$, along it from the North Atlantic into the Norwegian Sea. The interested reader will find a very comprehensive discussion of the IFF in the paper by Hansen and Østerhus (2000).

The images of sea surface temperature also allow us to determine where surface fronts are most likely to be found. From an analysis of twelve years of satellite data, Belkin et al. (2003) show that the IFF leaves the east Iceland coast near Eystrahorn at $64^{\circ} 30^{\prime} \mathrm{N}$ first towards the northeast and then southeast along the northern slope of the ridge between Iceland and the Faroes (Figure 8). This accords with Stefánsson (1972) who wrote that the front demarking the warm and cold waters just offshore of Iceland migrates seasonally no more than about 35 nautical miles (nm). From a navigational point of view the stability of the front may have been quite useful. Returning to Carta Marina, it seems that the mariners knew where to find the region of contrasting waters, as indicated by the mean path of the whorls. But they also knew that they likely would be traversing a variable field of warm and cold pockets 


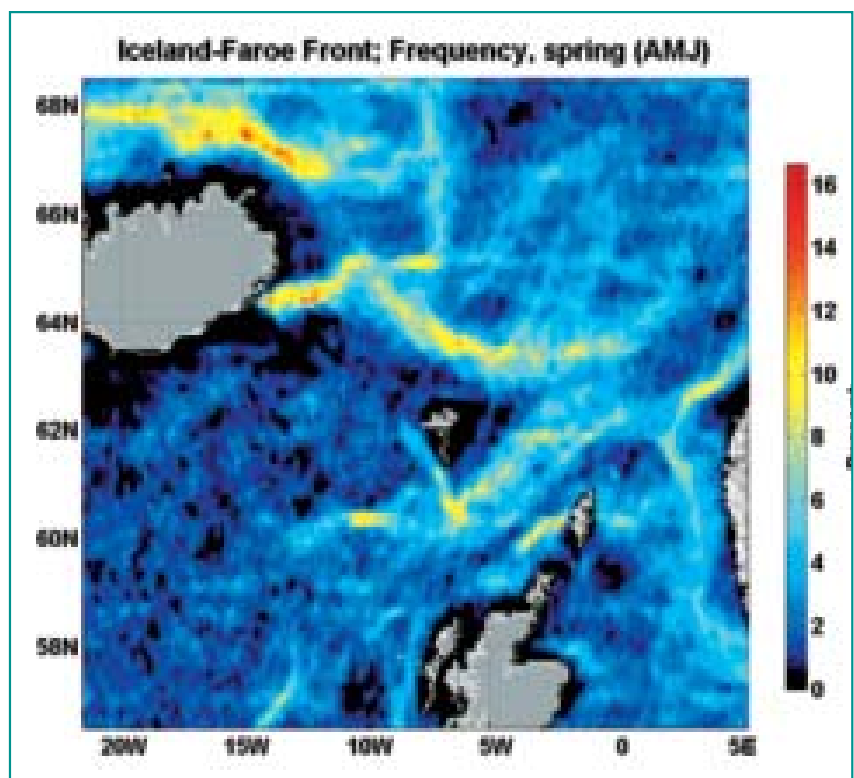

Figure 8. Long-term (1985-1996) frequency of occurrence of SST fronts in spring (April-June) in the IcelandFaroe-Shetland region, based on twice-daily 9- $\mathrm{km}$ resolution AVHRR SST images from the NOAA satellites processed with the Cayula-Cornillon algorithms for cloud screening and front detection. The color scale shows the percentage of the total cloud-free time that a given $9 \mathrm{~km} \times 9 \mathrm{~km}$ pixel contained a front. This picture was kindly provided by Igor Belkin (see Belkin et al., 2003 for further information).

on their journey to Iceland, hence the whorls with a scale of roughly $100 \mathrm{~km}$. We should not make too much of the size comparison; nonetheless, given the similarity of scale, the agreement in location, Olaus' evident desire to be informative, and the fact that he calls the map Carta Marina all suggest that he drew the whorls there for a specific reason. Further, the band of whorls extends only to a point north or northeast of the Faroes, they do not continue east towards Norway nor north into the Norwegian Sea. This may be significant because the Iceland-Faroe Front turns northeast and weakens in thermal contrast. And perhaps just as important, Olaus does not draw whorls like these anywhere else in Carta Marina.

Coherent structures such as an eddy or meander require a circulation or flow to maintain their structure for any length of time. This means our mariners also should have observed currents or changes in currents as they sailed towards Iceland. How large are these currents, and could the mariners have detected them? This seems likely. First, as mentioned earlier, the Kogge and the larger Holk were unlikely to exceed 5 knot speeds and then only with a favorable tailwind. The $1000 \mathrm{~nm}$ transit from Germany to Iceland took roughly one month according to Baasch (1889). This translates into a mean speed of 1.5 knots, not a very large speed, and only twice this if hove to half the time

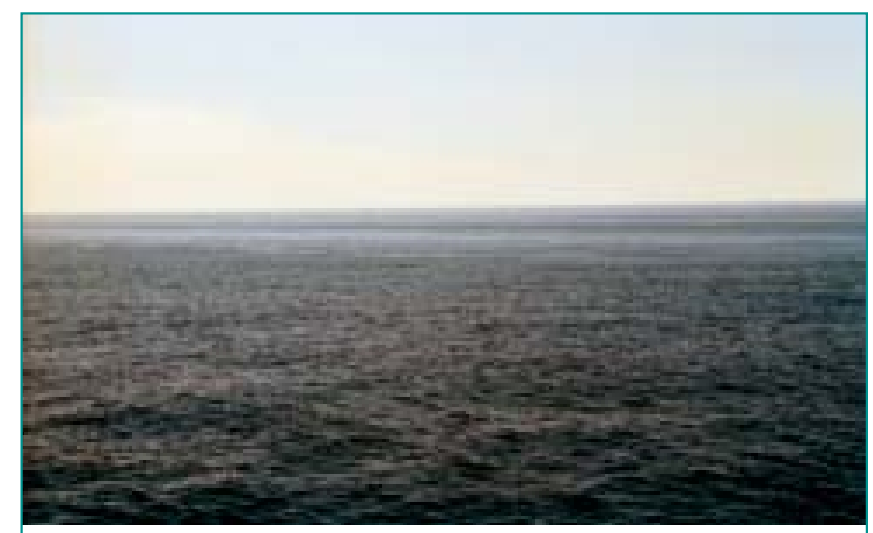

Figure 9. An example of a surface front as might be seen by a mariner. The bright and dark bands reflect variations in surface wave roughness due to converging and diverging bands of water.

waiting for suitable winds. (By way of comparison, Columbus made his $3100 \mathrm{~nm}$ transit from the Canaries to San Salvador in only 33 days, a mean speed of 4 knots, but then he had the benefit of the very steady NE trade winds.)

The IFF delineates the boundary between the warm salty waters of the North Atlantic and the cold waters flowing east along the north coast of Iceland. Such a strong temperature contrast can only be maintained by means of a persistent flow towards and along the front. It seems likely that navigators of the time were aware of such mean flows. First, the distribution of the whorls point to an eastward spreading. Second, given the large size of the merchant fleet approaching Iceland each year, it seems likely that they would notice which routes tended to require the least transit time. Keeping in mind the number of vessels that visited Iceland each year, century after century, it seems self-evident that the seafarers had extensive knowledge about the best ways to sail to Iceland. Even a $13^{\text {th }}$ century text, Konungs skuggsjá (Anon., 1976), discusses in detail when not to head out on the high seas and why, the presence of maelstroms (whorls?), and existence of wind-accelerated surface currents.

\section{Navigational Clues}

Given the limited navigational capabilities 500 years ago, vessels were not likely to notice changes in course made good unless the currents were strong enough for long enough that a change in latitude could be detected. On the other hand changes in course might be easier to detect between Iceland and the Faroes, and especially close to Iceland where the snow-covered $1000 \mathrm{~m}$ high eastern mountain range on clear days might be visible $50 \mathrm{~nm}$ out to sea. They might also have noticed that as they left Iceland the front stayed in about the same place close to shore, but farther to east it could vary in position such that 


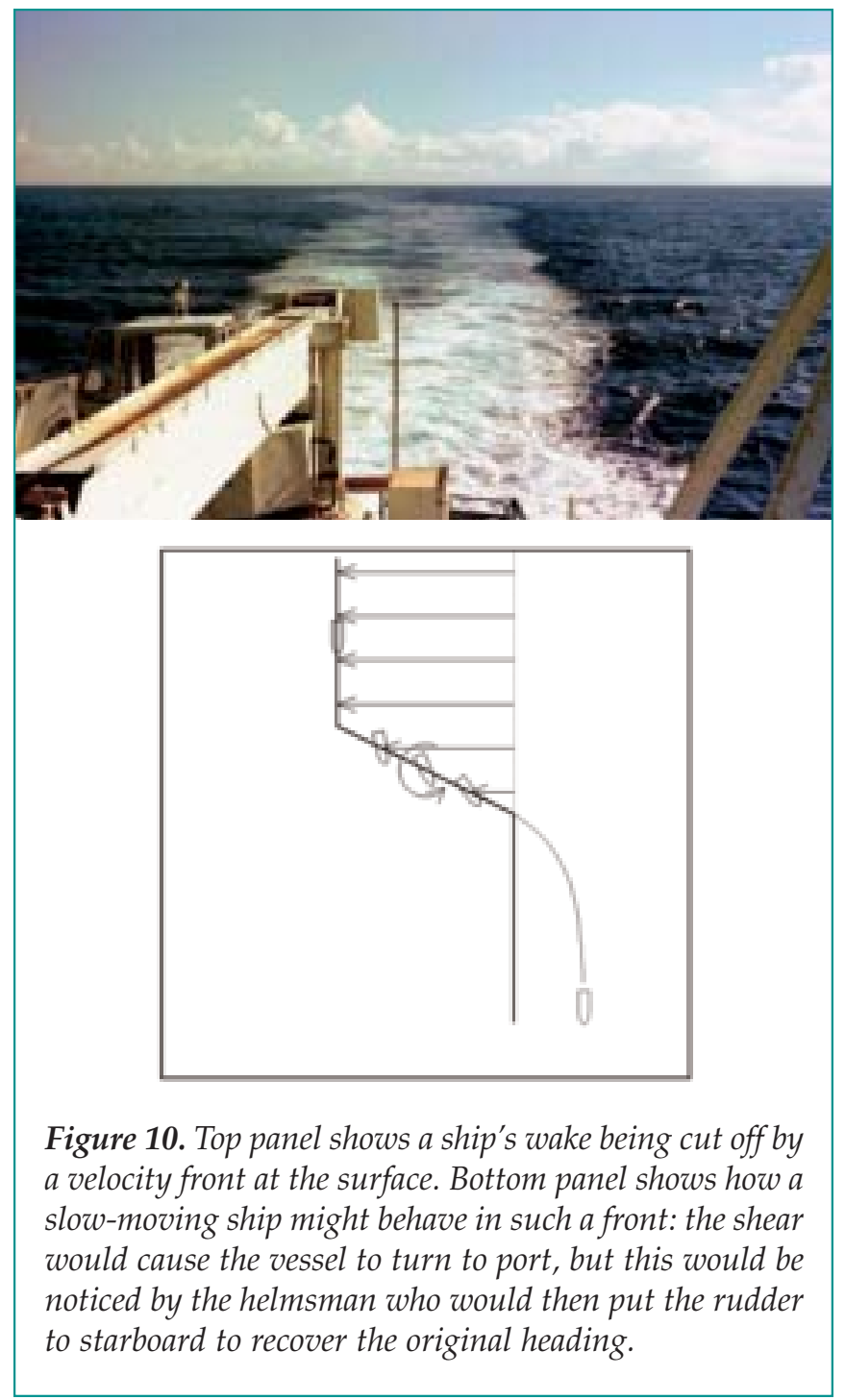

sailing along a constant heading the temperatures could vary widely. Keen observers as they undoubtedly were, they would also notice changes in surface wave structure and perhaps velocity as they crossed surface fronts.

Slick lines signify a surface front and often wave patterns will have a different character to either side, shiny on one side and rough on the other. Figure 9 shows a picture of such a front near the Laurentian channel across the continental shelf east of Nova Scotia. At a distance the difference in surface roughness shows up clearly (the dark and shiny zones) whereas close up one can see concentrations of surface flotsam due to convergent flows at the surface. Such fronts may separate waters with different properties such as temperature and color. Figure 10 (top) shows the wake from a research vessel after crossing the North Wall of the Gulf Stream. Notice how the wake does not continue straight back but is cut off and shifted to the left by the jump in velocity at the surface. A slow moving holk would not leave a long wake, but it very likely would be affected by the shear as it crosses a front. Specifically, the shear will cause the vessel to rotate and point in a different direction as it passes through the shear zone, as indicated in the lower panel. The heading change will depend upon the velocity difference across the shear zone and the time required to traverse it. Typical maximum surface currents in the IFF and eddies can range up to 2 knots. This is not insignificant for a slow-moving vessel. Given a front where the velocity changes linearly, $\mathrm{dv} / \mathrm{dx}$, and that it takes a vessel $\mathrm{T}$ (seconds) to traverse it, the change in the vessel's heading in degrees due to the shear will be $\mathrm{dv} / \mathrm{d} \times \mathrm{x} \mathrm{T} \times 57.3(\% / \mathrm{rad})$. Assuming a velocity change of $0.5 \mathrm{~ms}^{-1}$ over $100 \mathrm{~m}(\mathrm{dv} / \mathrm{dx}=0.005$ $\mathrm{s}^{-1}$ ) and a vessel speed of 2 knots such that it takes100 s to cross the front, the change in heading would be 0.005 $x 100 \times 57.3=29^{\circ}$ or almost three points on the 32 point compass rose in common use in those times. This would be very apparent to the helmsman. As our ancient sailors crossed through what they perceived to be pools of cold water, sometimes bounded by regions of sharp change in velocity, the step to representing these as whorls in Carta Marina does not seem farfetched. That some are larger than others would also not surprise, hence the variation in size of the whorls in Figure 5.

Ocean color varies with water type. Generally speaking the warm waters from the North Atlantic would have a somewhat deeper blue color than those from the cold East Iceland Current. Stefánsson (1972) mentions that the frontal zone southeast of Iceland is often very sharply defined. Marine life would also have a different character and might be particularly active along the front itself due to upwelling of nutrient-rich waters from below. Such waters can support a high production of phytoplankton, grazing zooplankton, and so on up the food chain. On a cruise to the IFF region this summer, we saw numerous slick lines due to organic material that reduces the surface tension and hence the roughness of the surface. Also, on one occasion we passed through an assembly of pilot whales easily numbered in the hundreds, a truly extraordinary sight. The frolicking whales around us made the marine fauna in Carta Marina seem very believable. We have no information on how our ancient mariners experienced and recorded their observations of currents and marine life, but we can be sure they would use everything they saw as best they could to improve their navigational capability and safety at sea. The incidences where a vessel did not find Iceland appear to have been few (Baasch, 1889).

There exists one other map (that we know of) that possibly portrays thermal patterns or whorls in the ocean. It is located at the Bibliotheque Royale in Brussels, Belgium (Codex Ms 14887). Most likely drawn by a Jan van Kriekenborch (or someone in his workshop) in 1485, it is based on a map of Scandinavia included in a production of Ptolemy's Geography published by Nicolaus Germanus in Ulm in 1482. Since Ptolemy did not know the northern limits of the old 


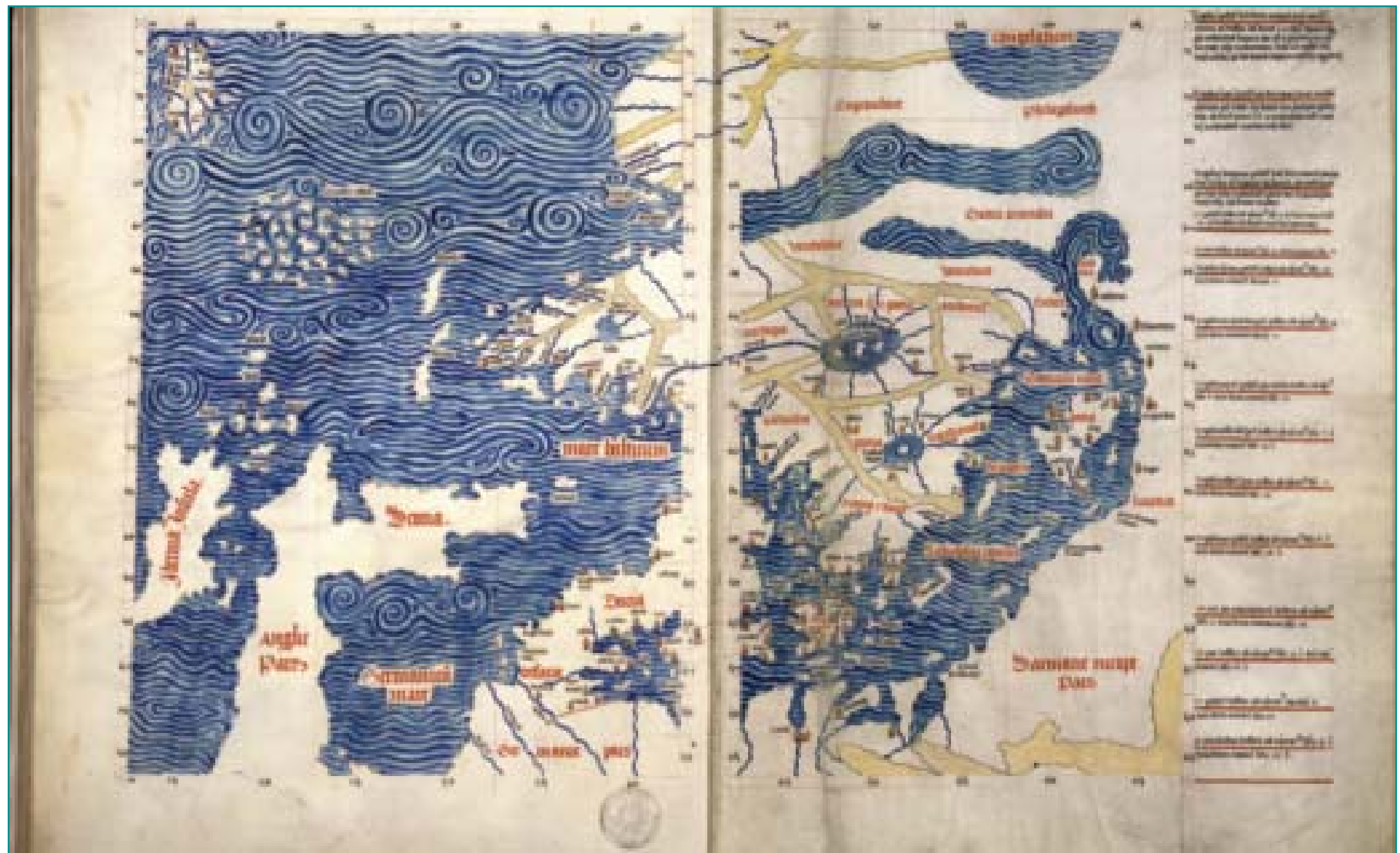

Figure 11. Map (original size 0.651 x $0.450 \mathrm{~m}$ ) of Scandinavia in Ms 14887, Bibliotheque Royale, Brussels, Belgium. From annotations in Ms 14887 a likely date for the map is 1485 (Reproduced with permission from Bibliotheque Royale, Brussels, Belgium.)

hemisphere (Scandinavia is limited to two islands, Scandia and Thule), geographers composed new maps to correct those of Ptolemy. This particular map of Scandinavia, which is the last of four additional maps in the Ptolemy Geography in 'The Library of Raphael de Marcatellis' (Derolez, 1979), clearly shows Scandinavia as a peninsula although not yet fully developed in the north-south direction. But what interests us here is the fact that the map gives the ocean a physical presence in the form of gently waving blue lines. This, in itself, is rather unusual, but what is even more remarkable, the lines turn into whorls in the north, to the right of Iceland in the upper left corner (Figure 11). Unquestionably the bright blue lines and whorls have enormous esthetic appeal, but it is tempting to think that the whorls have a more than decorative purpose, for here, as in Carta Marina, they do not populate the map as a whole, but cluster in a particular area corresponding to that of the IFF. We do not know if the original map by Nicolaus Germanus included these whorls. Living in the monastery of Reichenbach near Regensburg in southern Germany before moving to Italy, he may not have had much contact with the Hanseatic League, but van Kriekenborch, living in Ghent, a port and manufacturing city in Belgium, could very well have had contact with mariners and heard their descriptions of sailing conditions in the northern North Atlantic.

\section{Summary}

Carta Marina and the companion 'HISTORIA...' by Olaus Magnus brought the northern countries to the attention of Europe at a time of rapid development from a medieval, rather provincial frame of mind to a keen awareness of worlds far beyond the Mediterranean. He brought to Europe a vivid and detailed description of the geography and peoples of the Nordic countries. Thus his Carta Marina can be studied on many levels. It's fascinating to discover how the more you probe the map the greater the wealth of information to emerge.

The whorls drawn in the ocean exemplify this richness of information embedded in the map. Their location, size and spacing seem too deliberate to be a purely artistic expression. Instead, we suggest that they represent what we today call the Iceland-Faroe Front, a meandering front that separates the warm waters flowing north between Iceland and the Faroes from the cold waters flowing east and south around the northern coast of Iceland. The $5^{\circ} \mathrm{C}$ temperature difference between these two waters can often appear as sharp changes in sea surface temperature along the meandering front. Unquestionably mariners were keenly aware of these variations in temperature, and likely noticed variations in surface currents as well. However, in those days they had neither the instruments to quantify these 
observations nor the means to express them. Against this backdrop or lack of tools of expression, the whorls in Carta Marina appear to be a surprisingly accurate representation of today's meandering front and the intermittent formation of warm and cold eddies to either side. The fact that the eddies appear as an eastward extension of sea ice north of Iceland could also indicate that Olaus envisioned his whorls as pools of melted ice. Sailing very close to the waters, these thermal contrasts must have been well known to earlier generations of Iceland farers including Norse Vikings, the first major settlers of Iceland. The whorls in the Brussels map might possibly be interpreted in a similar light. But at present we do not know how to develop this conjecture further. Our reading of the Carta Marina literature has not brought us any information that might give insight or substantiation to the meaning of the whorls. Indeed, the significance of the whorls apparently got lost rather quickly. When the map was reissued as a copper print in 1572 by Antoine Lafrère, everything in it, including the ships and marine fauna, was faithfully reproduced, but the whorls were omitted! 空

\section{Acknowledgements}

We thank Prof. Teddy Brunius and Map Curator Åsa Henningsson, both at the University of Uppsala, for enlightening discussions and helpful comments about Carta Marina. Special thanks are due Dr. Charlotta Scheich at the Catholic University of Louvain, Belgium for help in researching the Brussels Ms 14887. Drs. Elke Burkhardt and Olaf Boebel at the Alfred Wegener Institute provided generous assistance in locating several books and references. Dr. Johan Blindheim at the Marine Research Institute in Bergen brought the book 'Konungs skuggsjá' to our attention. The comments from reviewers Igor Belgin and Bogi Hansen were very much appreciated.

A colored version of Carta Marina can be viewed at http:/ /bell.lib.umn.edu/map/OLAUS/carta.html.

\section{References}

Anon, 1976: Kongspegelen. Norwegian translation of Konungs skuggsjá, a 13th century book of good manners and conduct written in the form of a dialogue between a king and his son. Det Norske Samlaget, Oslo. 228 p. The book is also available in English as 'The King's Mirror, 1917. American-Scandinavian Foundation.

Baasch, Ernst, 1889: Forschungen zur hamburgischen Handelsgeschichte. 1. Die Islandsfahrt der Deutschen. Hamburg, 140 p.

Belkin, I.M., P. Cornillon, D. Ullman, and Z. Shan, 2003: Global pattern of ocean fronts from Pathfinder SST data: I. Atlantic Ocean. To be submitted to J. Geophys. Res.

Codex Ms 14887. Manuscript from the library of Raphael de Marcatellis which includes the map of
Scandinavia in Figure 11. Most likely from 1485.

Derolez, A., 1979: The library of Raphael de Marcatellis, Abbot of St. Bavon's, Ghent, 1437-1508. E. StoryScientia Ltd. Ghent, 335, 48-53.

Ellmers, Detlev, 1999/2000: Zur Herkunft des spätmittelalterlichen Schiffstyps Holk. Zeitschrift für Archäologie des Mittelalters, 27/28, 119-128.

Ellmers, Detlev, 2002: English summary of 'Old Sea Book from the 14th century', (Personal communication).

Granlund, John, 1951: The Carta Marina of Olaus Magnus. Imago Mundi 8, 35-43.

Grape, Hjalmar, 1970: Olaus Magnus forskare moralist konstnär. Propius Förlag, Stockholm, 245 p.

Helland-Hansen, B. and F. Nansen, 1909: The Norwegian Sea: its physical oceanography based upon the Norwegian researchers 1900-1904. Report on Norwegian Fishery and Marine Investigations, 2(2), $390 \mathrm{p}$.

Hansen, B. and S. Østerhus, 2000: North Atlantic-Nordic Seas exchanges. Prog. Oceanogr., 45, 109-208.

Knauer, Elfriede Regina, 1981: Die Carta Marina des Olaus Magnus von 1539. Ein kartographisches Meisterwerk und seine Wirkung. Göttingen Gratia-Verlag Heft $10,151 \mathrm{p}$.

Lamb, H.H., 1977: Climate, present, past and future. Volume 2: Climatic history and the future. Methuen \& Co. Ltd., 835 p.

Magnus, Olaus, 1555: HISTORIA DE GENTIBUS SEPTENTRIONALIBUS. ROMA. Translated into the Swedish 1909-1925. Reissued in 1976 and in pocket 2001. Gidlunds Förlag, 1087 p.

Nordenskiöld, A.E., 1889: Facsimile Atlas to the early history of cartography. Stockholm, Sweden. Reissued by Dover Publications in 1973.

Richter, Herman, 1967: Olaus Magnus Carta Marina 1539. Lund (Lychnos-Bibliotek 11,2). Almquist \& Wiksell. Stockholm, $195 \mathrm{p}$.

Stefánsson, U., 1972: Near-shore fluctuations of the frontal zone southeast of Iceland. ICES Rapp. P.-v., 162, 201-205.

Waters, D.W., 1958: The Art of NAVIGATION in England in Elizabethan and Early Stuart Times. Yale University Press, New Haven, 696 p.

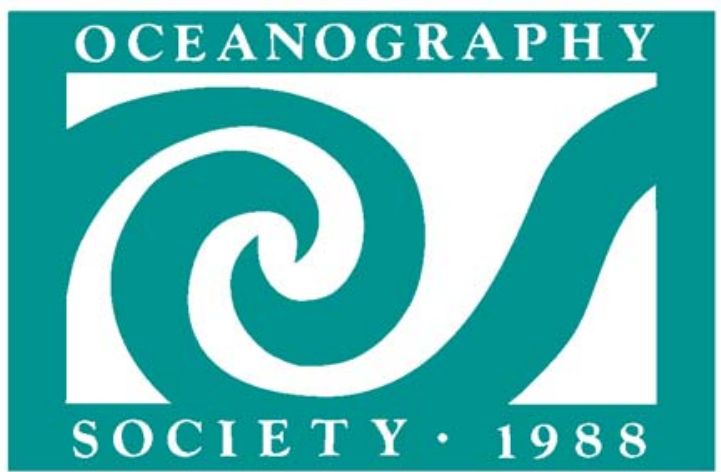

